\title{
Gender Sensitivity Issues in Short Stories
}

\author{
Edna Cardinosa- Queriones \\ Pangasinan State University-Lingayen Campus, Philippines
}

\begin{abstract}
This study is a hybridized research which consists of the qualitative and quantitative data. It determined the trend of manifestation of the different themes of gender sensitivity in short stories and looked into the difference in the trend of manifestation of the different themes and the relationship with the sex of the short story writers. The findings revealed that the theme on how women are hindered for political career was the theme that mostly occurs on the selected short stories written by males with nine or 45 percent trend of manifestation. However, with the selected short stories written by females, the themes on women's vulnerability to poverty and the discrimination of women for employment appear with the most number of occurrences of four or 23.53 percent. There was an observed difference in the trend of manifestation between the males and the female writers. However in the Kruskall Wallis statistical test revealed that there was no sufficient evidence to conclude gender differences in the themes. Furthermore, the sex of the short story writers does not affect the trend of manifestation of the different themes embodying the different gender sensitivity issue in the selected short stories except with the gender sensitivity issue on Poverty. The researcher concluded that short stories contain different themes reflecting the various gender sensitivity issues which vary in the trend of manifestation. The study recommends that Filipino writers should write more stories depicting the role of Filipino woman and emphasize their importance in the society.
\end{abstract}

Keywords: gender sensitivity issues, short stories, women

\section{Introduction}

At the moment of birth, a human being is defined as being a boy or a girl. Everything a person does with her or his life is dependent on that simple categorization. Socialization, specifically gender socialization, begins with family as the primary agent and later other agents of socialization become more influential. Children are bombarded with diverse messages, images and representations of gender, constructing a dreamlike world of childhood innocence (Leaper, 2007).

Women in the Philippines now are not only seen at home, taking care of the children, doing the laundry, cleaning the house and preparing everything before her husband arrived home from work. They are also seen perform the same task given to men. They are seen fighting for truth, struggling to improve the economy, operating machines and even offering their lives to others.

The combination of the persistence of traditional gender ideologies and changes in economic and social realities makes today's workplace a particularly contentious arena for working out gender issues. On the other hand, women face persistent discrimination based on their gender: They are paid less, promoted less often, and assigned to specific jobs despite their qualifications and motivations; and they are made to feel unwelcome, like intruders into an all-male preserve. (Kimmel, 2004)

Today women had successfully invaded the world of work but still she does her responsibility at home with prowess and she never complains for all the things she does because she is a Filipino woman.

According to Vibal (2008), "To achieve great success in life one must be willing to walk the extra mile". In a sense, this quote may apply to the women of the Philippines, who have struggled so hard and for so long for recognition and equality in a world which had viewed them as second-class citizens and even as chattels. Where the efforts of men were easily recognized, Filipino women had to walk the extra mile just to have their contributions acknowledged. Despite this, Filipino women have achieved much. They fought for their country's independence alongside their men, and when that 
independence was achieved, they have contributed to the best of their ability to the building of their nation. But this does not mean that women had taken control over men.

The pursuit of equal rights for women has been a slow process. Several issues which are questionable in describing gender sensitivity are still reflected in the different aspects of human life.

Women of today are active in medical sciences, law, engineering and architecture. As a proof, women power dominated the 2007 bar examination with Mercidita as the topnotch (Frialde 2008). Women are also active in sports and outdoor activities. They are now free to engage in any activities which they think will suit their personalities and gain additional knowledge and skills.

In Literature, the evolution of the struggle of Filipino women for equality is undeniably expressed and emphasized by both male and female writers. Gender sensitive issues are depicted in some literary writings but definitely become helpful and educative. Though there are some points of inequality, this was necessary to show and understand the society.

The concept to identify the different issues of Gender Sensitivity in Literature most particularly in short stories is to analyze the content of such literary writing. Perhaps due to the fact that it can be applied to examine any piece of writing or occurrence of recorded communication, content analysis is currently used in a dizzying array of fields, ranging from marketing and media studies, to literature and rhetoric, ethnography and cultural studies, gender and age issues, sociology and political science, psychology and cognitive science, and many other fields of inquiry. Additionally, content analysis reflects a close relationship with socio- and psycholinguistics, and is playing an integral role in the development of artificial intelligence.

This study aimed to determine and analyze the thematic content which embodies the different gender sensitivity issues of ten selected short stories written by well-known Filipino writers. Specifically, it sought to answer the following questions; (1) What are the themes of the selected short stories of Filipino writers embodying different issues on gender sensitivity along;a.) Poverty; b.) Employment; c.) Health Care; d.) Education and e.) Politics (2) What is the trend of manifestation of the different themes of the selected ten (10) short stories embodying the different gender sensitivity issues employed, according to the sex of the short story writers? (3) Is there a significant difference in the trend of manifestation of the different themes embodying the different issues of gender sensitivity between male and female short story writers? (4) Is there a significant relationship between the sex of the short story writers and the trend of manifestation of the different themes embodying the different issues on gender sensitivity?

This study focused on analyzing the thematic content which embodies the different issues on gender sensitivity of the ten selected short stories of well-known Filipino writers.

It also dealt on finding out the trend of manifestation of the different themes of the ten short stories embodying the different issues on gender sensitivity and the relationship between sex of the well-known Filipino short story writers and the frequency of the manifestation of the different themes embodying the different issues on gender sensitivity.

The researcher made used of ten (10) selected short stories written by well-known Filipino short story writers. These short stories are Footnote to Youth by Jose Garcia Villa, Weddding Dance by Amador Daguio, Zita by Arturo Rotor May Day Eve by Nick Joaquin, How my Brother Leon Brought Home a Wife by Manuel Arguilla, The Virgin by Kerima Polotan Tuvera, Maternity Leave by Ligaya Victorio-Reyes, Dead Stars by Paz Marquez-Benitez, Love in the Cornhusk by Aida Rivera-Ford and Desire by Paz Latorena.

\section{Methods and Materials}

This study have focused on the themes of ten selected short stories of Filipino writers embodying the different issues on Gender sensitivity along; poverty, employment, healthcare, education and politics. It involved establishing categories and then determined the occurrences as they are used in the text.

In the selection of the short stories, the researcher gathered the needed data through library research and identified the different short stories written by well-known Filipino writers

Moreover, the researcher determined the different gender sensitivity issues which are; Poverty, Employment, Healthcare, Education and Politics based on the Various Rights of Women which are Economic Right, Right to Education, Right to Work, Right to Health and Political Right. (http://www.rightsreporting.net2010) 
Categories of themes were made to describe the portrayals of women in the different selected short stories which embody the different issues on gender sensitivity. Careful and intensive reading of the different short stories was employed with the end in view of identifying the different themes of the short stories.

Finally, the researcher content analyzed the different themes of the different short stories written by the Filipino writers embodying the different issues on gender sensitivity.

The researcher have determined the occurrence of the different gender sensitivity issues embodied in the theme of the selected Filipino short stories by well- known Filipino writers through content analysis, The short stories were particularly written during the pre-war period from 1925-1941.

The researcher identified the different themes of the short stories written by five (5) male and five (5) female Filipino writers in terms of the different ideas on gender sensitivity using the categories and subcategories which is a description of the portrayals of women in the selected short stories made by the researcher based on the different principles in identifying the theme by Steven Dow Cowan's "Short Story Theme and Ideas" (2011).

Simple frequency counts and percentages, non-parametric Kruskall Wallis Ranked Sum test and the Chi Square test were used in this study.

\section{Results and Discussions}

The themes reflecting different issues on Gender Sensitivity in selected short stories were determined according to the different issues on gender sensitivity such as: Poverty, Employment, Healthcare, Education and Politics. These themes are stated into five categories, namely: (1) Themes that considers women's vulnerability to poverty (2) Themes that describes women's discrimination for employment and desires for higher positions (3) Themes that portrays unfavorable treatment for women's healthcare (4) Themes that shows women's limitations/hindrance to acquire further education, and (5) Themes that demonstrates women's hindrance for political career and renders them invisible and mere follower.

\section{Table 1}

\section{Categories of Themes Embodying Various Gender}

\section{Sensitivity Issues in Selected Short Stories}

\begin{tabular}{|l|l|}
\hline Gender Sensitivity Issues & Categories of Themes on Women of Selected Short Stories \\
\hline POVERTY & Vulnerability to poverty \\
\hline EMPLOYMENT & Discrimination for employment and desires for higher positions \\
\hline HEALTHCARE & Unfavorable treatment for healthcare \\
\hline EDUCATION & Limitations and hindrance to acquire further education \\
\hline POLITICS & Hindrance for political career which renders them invisible and mere follower. \\
\hline
\end{tabular}

\section{Themes on Women's Vulnerability to Poverty}

From the stories, Footnote to Youth, Wedding Dance and Love in the Cornhusk revealed the theme that women are vulnerable to poverty. The theme depicts women just performing house related duties such as taking care of the children, cooking, laundering and washing the dishes demonstrated by Dodong's mother and his wife, (Footnote to Youth).In like manner, Lumnay (Wedding Dance) is seen planting beans, cleaning water jars and keeping the house clean.

They further illustrates about working mothers who worry about Maternity Leave which is one of the benefits a woman employee should enjoy after giving birth, but in the case of Lucia, the main character in the short story (Maternity Leave), worries about her absence in her work because this would mean earning little amount for her family and spending much after a little time to breast feed would spend for the babies food and formula milk. However with Tinang (Love in the 
Cornhusk) having babies in a hurry would mean additional expense for she would be thinking of the basic needs of not just one baby but two babies instead, thus poverty sets in for this particular situation of women.

\section{Themes on Women's Discrimination for}

\section{Employment and Desires for Higher Positions}

The short story Maternity Leave by Ligaya Victorio- Reyes shows how women are discriminated in the workplace because of the reproductive role of woman and that is giving birth. Woman, who should be excited for having a baby becomes worried, instead, because of the consequences or punishment brought by their maternity leaves.

The idea above further shows that the short story Maternity Leave reveals that women are discriminated because of their role as mother. To be a mother is a joy a woman could ever have, but because of the less benefit and assurance given to them worries set in.

In the story Desire, the statement above shows that a woman who is the main character was not believed to write such delightful sketches and letters not only because she is unattractive but so because she's a woman. The story shows how women are regarded as less knowledgeable and talented when it comes to what they could do; they are believed to be inferior to man.

With the story "Zita" by Arturo Rotor, the protagonist of the story is a girl who is told to please a man and pays respect to him. The short story reflects how women are discriminated for they are only considered as just mere follower of men. In the story, only men and recognized and perform the role of a teacher and who should be given respect because he is a man.

Traditionally, women do all the household related chores, but the heavy works that require more strength is done by the husband. The scope of their functions include cooking, cleaning, teaching the children, washing clothes, repairs, budgeting, and helping in the farm. The husband is the one who makes sure the farm would yield quality crops, so he does all the maintenance works. In some cases, where the husband needs help from other men, the wife would make sure that the men are fed, so she cooks food and bring it to the farm. The Filipino women, ensures that everyone is well fed, and this characteristics extends to the workers, relatives, or visitors.

In general, Filipino women find pride in their work. They do not find themselves alienated from their chores because they work with, around, and for their families. This family-oriented mind set gives them a sense of dignity and responsibility. The family and the children are the primary priority in a Filipina's life.(Clamonte,2007)

\section{Themes on Women's UnfavorableTreatment}

\section{for Healthcare}

The main character of the short story Footnote to Youth is Dodong but the realization of his action was the difficulties of Teang, his wife. Eventhough Dodong knew how difficult life is, he still had married Teang, and because of this, they have lived the life of misery where at a very young age had children of her own. This is also reflected when Teang because of giving birth to seven children, became shapeless and thin. This shouldn't had happen if Dodong and Teang have waited for the right time to get married and be matured enough to go through the difficulties of life. Because of early marriage which brought them financial burden, the health of the wife was at stake.

To bear a child is a woman's role, but this role is not easy when having it is a burden. This is about the short story Maternity Leave by Arturo Rotor. The story shows the theme on how woman's healthcare is treated unfairly which is the struggle of a woman as a mother who believes that to be a mother is a real happiness for women, but one must prepare for it emotionally, financially and prepare for it physically.

In the story, Wedding Dance Awiyao has to leave Lumnay and marry another woman, for inspite of being a great wife; Lumnay can't give him a child. The inability to have a child is not the fault of only one, but in the story it is what is reflected - Awiyao may carry the burden but it is much with Lumnay, the woman, the wife because she will be left alone by the man she had loved. 


\section{Themes on Women's Limitations/Hindrances}

\section{To Acquire Further Education}

The unequal chances of Filipino women to acquire further education could be seen in the different short stories under study. Filipino women are shown to be less educated or even illiterate compared to men who were portrayed as a teacher or someone who dominate women.

A woman who suffers belittlement due to lack of education is shown in the short story by Aida Rivera Ford. Tinang, the main character in the short story was thought to be illiterate because of he $r$ physical appearance. Filipino women are those who play the role of a housemaid and regarded as less educated compared to men who are well dressed and respected.

Acquiring education is one of the many stuggles of Filipino women which is also portrayed in the short story, Desire by Paz Latorena. The story of Paz Latorena was about a woman who wanted to be loved not because of her body but because of what is everything about her. The main character is a woman who is homely but molded with a body of unusual beauty.

The short story was written during the time that was very repressive and judgmental for women. It was the time where beauty is just skin deep, more often than not face value is more important than the inner side of a woman.

\section{Themes on Women's who are hindered for Political}

\section{Career and Rendered them Invisible and Mere Follower}

The setting of the short story Wedding Dance happens somewhere in the North, specifically in Ifugao where a traditional wedding dance is practiced. There is a belief that a man should have a child and to have none, is forbidden. It is said that there is an unwritten law that a man may take another woman if his wife can't give him a child. In the mountains before where some Filipinos belonging to ethnic groups rely more on their traditions and culture.

The short story Zita by Atruro Rotor is reflective of the alienating nature of the society during the time of its writing, especially in how society wants women to be: how they should dress, their manner, etc., and how these norms that society is imposing result in new and difficult issues for women of that period in history. This is a Gender Sensitivity Issue on Politics which has something to do with the norms and tradition of the society.

With the lines of Agueda it expresses how she hated Badoy so much, not because of his status but because she sees him as a representation of men who were given priviliges to acquire education. The development of Agueda's character in the short story, May Day Eve shows the status of women in the society. Politically, during this time, men were regarded to be dominating women.

In the story, My Brother Brought Home a Wife, Leon arrived with his wife in the province. They took a surprising route home for Leon, but it was meant as a test for the wife to see if she could endure the sacrifices she made and meet her new family.

\section{Table 2}

The Frequency of Occurrence of the Different themes of the Selected Short Stories

\begin{tabular}{|c|c|c|c|c|c|}
\hline \multirow[t]{2}{*}{ Short Story Writers } & \multicolumn{5}{|c|}{ CATEGORIES } \\
\hline & Poverty & Employment & Healthcare & Education & Politics \\
\hline Male writers & 3 & 1 & 6 & 1 & 9 \\
\hline Female writers & 4 & 4 & 3 & 3 & 3 \\
\hline Total & 7 & 5 & 9 & 4 & 12 \\
\hline
\end{tabular}

The number of uccurences of the themes on each of the short stories analyzed cleary indicates the trend of manifestations of the different themes implicitly stated in the selected short stories of male and female writers. 
The theme depicting the category on politics had most number of nine occurences among the short stories written by male; six occurences for healthcare; three times for poverty, and once for employment and education.

On the other hand, for the female writers four occurences were noted for each of the gender sensitivity issues on poverty and employment and three occurences were also noted for healthcare, education and politics.

Overall, the gender sensitivity on politics got the highest number of twelve occurences while gender sensitivity on education got the least of occurences which is four.

These findings with regards to politics garnering the highest frequency of occurences being the most emphasized issue in the selected stories can be attributed to the fact that the short stories under study were written during then period where the unwritten law were religiously followed by the Filipinos. The loves of the Filipinos were based from the traditions, beliefs and customs which governed the community.

Table 3

\section{Summary of the Trend of Manifestation or the Total Occurrences of the}

\section{Different Themes of Gender Sensitivity Issues in Short Stories}

\begin{tabular}{|c|c|c|c|c|}
\hline \multirow{3}{*}{$\begin{array}{l}\text { Gender Sensitivity Issues } \\
\text { embodied in the selected Filipino } \\
\text { Short Stories }\end{array}$} & \multicolumn{4}{|c|}{ SEX } \\
\hline & \multicolumn{2}{|c|}{ MALE } & \multicolumn{2}{|c|}{ FEMALE } \\
\hline & Frequency & Percentage & Frequency & Percentage \\
\hline A. Poverty & 3 & 15 & 4 & 30 \\
\hline B. Employment & 1 & 5 & 4 & 17.5 \\
\hline C. Health Care & 6 & 30 & 3 & 17.5 \\
\hline D. Education & 1 & 5 & 3 & 17.5 \\
\hline E. Politics & 9 & 45 & 3 & 17.5 \\
\hline Total & 20 & 100 & 17 & 100 \\
\hline
\end{tabular}

The theme on how women are hindered for political career rendering them invisible and mere follower to man, had the most number of nine or $45 \%$ occurences in the short stories written by male writers; six or $30 \%$ occurences on how women's healthcare are unfavorably treated, three or $15 \%$ occyurences on how women are discriminated in terms of employment and the desire for higher positions; and one or $5 \%$ on each theme on how women are discriminated in terms of employment and the desire for higher positions and on how women are limited or hindered to acquire further education.

It is reavealed on Table 2.2 that with respect to short stories of female writers that the themes that women are vulnerable to poverty and on how women are discriminated in terms of employment and desire for higher position have the same number of four or $23.53 \%$ occurences for each gender sensitivity issues on poverty and employment. The themes on how women's healthcare in infavorably treated, how women are limited or hindered to acquire further education and how women are hindered for political career rendering the, invisible and mere follower to man relating to gender issues on healthcare, education, and politics, respectively, it had occurred three times or $17.65 \%$ frequency of manifestation on the different short stories of female writers.

The findings may mean that male writers prefer to write short stories with themes on gender sensitivity issues on politics, while female writers on gender sensitivity issues on poverty. These imply the evidence of superiority of men in dealing woith issues pertaining to politics because it depicts the ease of struggle against societal pressures. However, for female writers wrote short stories with theme on gender sensitivity issues on poverty as evidenced fior their acceptance for their traditional role of just staying at home doing householf chore and managing family's needs.

This study determined the significant difference between trend of manifestation of the different themes of the different short stories and the sex of the writers which was obtained using the Kruskall Wallis Rank Sum Comparison. 
Table 4

Difference between the Trends of Manifestation of the Different Themes Embodying the Different Issues of Gender Sensitivity

\section{And Sex of the Short Story Writers}

\begin{tabular}{|l|l|l|l|}
\hline Variables compared & KW Rank Sum & P & Conclusion \\
\hline Sex and Theme & $\begin{array}{l}\text { Male }=431 \\
\text { Female }=272\end{array}$ & 0.1201 & not significant \\
\hline
\end{tabular}

Table 3 shows an observed difference in the trends of manifestation of the different themes and the sex of the short story writers. However, using Kruskall Wallis statistical test, findings revealed that there was no sufficient statistical evidence to conclude gender differences in the thematic content of their short stories. Although the males have a considerably Kruskall Wallis sum of 431 as opposed to the females' 272 , the p value of .1201 indicates that this observed difference is not enough to warrant a significant difference between the males and the female short story writers at .05 level of significance.

\section{Table 5}

Relationship Between the Sex of the Short Story Writers and the Trend of Manifestation of the Different Themes Embodying

\section{the Different Issues on Gender Sensitivity}

\begin{tabular}{|l|l|l|l|}
\hline Theme & Chi Square & P-value & Conclusion \\
\hline A. Poverty & 3.9375 & 0.047 & Significant \\
B. Employment & 0.8333 & 0.361 & not significant \\
C. Health Care & 2.25 & 0.134 & not significant \\
D. Education & 0.4444 & 0.505 & not significant \\
E. Politics & 3.1111 & 0.2111 & not significant \\
\hline
\end{tabular}

It can be gleaned from Table 4 that the theme reflecting employment $(0.361)$; healthcare $(0.134)$; education $(0.505)$ and politics $(0.211)$ yielded a not significant result except with the gender sentivity issues on poverty with the $p$-value of $(0.07)$ which yielded a significant relation.

This means that female writers tend to write more on women doing household work while the male writers tend to write more on women who are sensitive about family's primary needs and conditions. In the rest of the themes, no gender differences were indicated using the Chi square test, although a noticeable trend was observed.

\section{Conclusions}

Based on the findings of the study, the researcher concluded that, short stories contain different themes reflecting the various gender sensitivity issues on poverty, employment, health care, education and politics. It was also found out that the trends of manifestation of the themes of the selected short stories vary.Furthermore, the theme of the short story is independent on the sex of the writers, However, there are mixed results in the relationship between the sex of the writers and the trend of manifestation in the use of the different categories of the thematic content.

\section{References}

Books

[1] Ariola, Purisima U. et. al.(2008) Philippine Literature : An Anthology. Lingayen, Pangasinan. Jentine Printing Press.

[2] Brabeck, Brown, L. (2001) Feminism Theory and Psychological Practice. Washington, DC. American Psychological Association.

[3] C. Legal documents and issuances 
[4] CIVIL SERVICE COMMISION. Office Order 307, s. 2004. The Constitution of the Gender Advocacy Group (GANG)

[5] CIVIL SERVICE COMMISSION RESOLUTION NO. 992781, s. 1999. Incorporating Gender and Development (GAD) Perspective in Civil Service Examinations.

[6] Craig (2002). The Effect of Day Part on Gender Portrayals in Television Commercials: A Content Analysis.

[7] D. Unpublished thesis

[8] De Leon, H. (2002). Textbook on the Philippine Constitution. Rex Book Store, Inc.

[9] Delos Santos, J. October (2005). Portrayal of Women on TV Soap Operas. University of Baguio.

[10] Dimalanta,Ophelia and Virginia Mata. (2001). Philippine Contemporary Literature in English.UST Publishing House.

[11] Dlomo, A. (2000) Management Today: Women in Leadership Today.

[12] Doubtfire Diane. (1996). Creative Writing New Edition. NTC Publication Group Ezzel, M. (2003) Writing Women's Literary

[13] Facura, Carmen C. March (1992). The Feminist Issues in the Selected Short Stories Of Kerima Polotan. Saint Louis University, Baguio City

[14] Fisher, Sabrina (2010). Powerful or Pretty: A Content Analysis of Gender Images in Children's Animated Films.

[15] Gerding, Ashton (2011). A Content Analysis of Tween Television Programming.

[16] Handbook of socialization: Theory and Research. New York: The Guildford Press.

[17] Henfridson, Hans (2008). A Thematic Analysis of Roald's Dahl's Adult Fiction. History, Houston: John Hopkins University.

[18] Kimmel, Michael S. (2004). The Gendered Society. New York: Oxford University Press.

[19] Lacia, Ferdilyn et al. (2008). The Literature of the Philippines Revised Edition. Rex Bookstore: Manila, Philippines.

[20] Leaper, Campbell \& Friedman, Carly Kay. (2007). The Socialization of Gender. In Joan E. Grusec \& Paul D. Hastings.

[21] Lopata, M. (2000). Integrated Work Career. Manila. National Bookstore.Lucia, Ferdilyn C. et al. (2008) The Literature of the

[22] Maccoby, Eleanor E. (2007). Historical Overview of Socialization - Research and Theory. New York: The Guildford Press.

[23] Maramba, Asuncion (2006). Early Philippine Literatute from Ancient Times to 1940 Revised Editon.

[24] Medina, B. (2001). The Filipino (2 $2^{\text {nd }}$ Ed.) Diliman. UP Press.

Patron, Ida. (2002). Philippine Literature.Great Books Trading. Quezon City.

Philippines. Quezon City. Rex Bookstote

Saymo,Apolinario S.(2004) Philippine Literature. Mecauayan, Bulacan. Trinitas Publishing.Tan, Arsenia (1995). Introduction to Literature $3^{\text {rd }}$ edition. Metro Manila. Academic Publishing Corporation

[25] Stone, L (2010). The Women's Journal.

[26] The 1987 Philippine Constitution.

[27] Tomelden, Yolanda V. and Thelma E. Arambulo et.al. (1990) Prism: An Introduction to Literature. National Bookstore.B. Journals

[28] Vallao, L. and Dela Cruz, M. March (2011). Portrayals of Filipino Women in Selected Contemporary Short Stories.

Pangasinan State University

[29] Villar, M. February (2008) Empowering Women. Manila Bulletin.

[30] Yanquiling, R. March (2007). Language Sexism in English Newspapers. Pangasinan State University

\section{E. Electronic sources}

http://www.un.org/esa/socdev/disrpeg.

http:www.unescap.org/sdd/issues/gender

http.//www.ehow.com/how-2246924-theme short story.html

www.merriam-webster.com/dictionary

http://en.wikipedia.org/wiki/gender

http://uk.oneworld.net/guides/gender

http://www.campus journalism.com

www.ched.gov.ph/policies/index.htm/\#1994

http:www.filipiniana. Net/collections/publication/

http://warlight.tripod.com/OPPERMANN.html

http:www.unfra.org/intercenter/role4men/empower.htm

http://www.newstimes.com/news/article/Hispanic-women-struggle-for-workplace-equality-250719.php

\section{APPENDIXA}

\section{The Ten Short Stories Used in the Study}

\section{ShortStories witten bymales}

Footnote to Youth

The Wedding Danœe

Zita by Jose Garcia Villa

by Amador T. Daguio

by Arturo Rotor 
May Day Eve

How My Brother Leon Brought Home A Wife

Short Storieswitten by females

The Virgin

Maternity Leave

Dead Stars

The Virgin

Love In The Comhusks by Nick Joaquin

by Manuel Arguilla

\author{
by Kerima Polotan Tuvera \\ byLigaya Victorio-Reyes \\ by Paz MarquezBenitez \\ by Kerima Polotan Tuvera \\ by AidaL. Rivera
}

\section{Short Story Writers Biography}

Short stories by Filipino writers showcase the Filipinos' talent as a story teller and as a writer. Philippine short stories have always been the country's most popular and well-liked literary genre.

They discuss a wide array of themes which varies from political to nationalist to present day social issues. Prior to the country's colonization, Filipinos already have their own short stories through their myths, legends, fables and folktales. Each region has its distinct form of storytelling and this made up the variety of Philippine short stories.

The early $20^{\text {th }}$ century also ushered in the writing talent of short story writers like: Jose Garcia Villa, Amador Daguio, Arturo Rotor, Nick Juoaquin, and Manuel Arguilla are the male writers. Kerima Tuvera, Ligaya Reyes, Paz Marquez- Benitez, Aida Rivera-Ford and Paz Latorena are among the female writers.

The following biographies of the different Filipino short story writers are from Philippine Literature books authored and edited by Lacia et al, (2008),Maramba, (2006) and Patron, (2002)

Jose Garcia Villa (August 5,1908-February 7,1997) was a Filipino poet, literary critic, short story writer and painter. He was awarded the National Artist of the Philippines title for Literature in 1973, as well as the Guggenheim Fellowship in creative writing by Conrad Aiken. He is known to have introduced the "reversed consonance time scheme" in writing poetry, as well as the extensive use of punctuation marks especially commas, which made him known as the Comma Poet. He used the penname Doveglion ( derived from "Dove, Eagle, Lion ) based on the characters he derived from himself.

Amador Daquio ( 1912-1966) was a poet, a novelist and a teacher during the pre-war. He was best known for his fictions and poems. HE had published two volumes of poetry, "Bataan Harvest" and "The Flaming Lyre". He served as chief editor for the Philippine House of Representatives before he died. Daquio was born in Laoag, llocos Norte, but grew up in Lubuagan, Mountain Province where his father an officer in the Philippine Constabulary, was assigned.

Arturo Rotor (1907-1988) was a medical doctor, a musician, and a writer. He was born in the Philippines on June 7, 1907. He attended the University of the Philippines, graduated from the Conservatory of Music and the College of Medicine. He trained further at John Hopkins University's medical school. During his time ther he and his co-workers discovered a rare form of jaundice now known as "Rotor Syndrome", Rotor published a paper on the disease in 1948. He was also a civil servant, serving as Executive secretary of the Philippine Commonwealth government in exile during World War. Immediate after the war, he was appointed Secretary of the Department of Health and Welfare. He also served as director of the University of the Philippines' Post Graduate School of Medicine.

Nicomedes Marquez Joaquin ( 1977-2004) was a Filipino writer, historian and journalist, best known for his short stories and novels in the English Language. He also wrote using the penname Quijano de Manila. Joaquin was conferred the rank and title of National Artist of the Philippines for Literature. After being honored as National Artist, Joaquin used his position to work for intellectual freedom in society. He is considered most important Filipino writer in English, and the third most important overall, after Jose Rizal and Claro M. Recto.

Manuel Estabillo Arguilla (1911-1944) was an llokano writer in English, patriot and martyr. He is known for his widely anthologized short story "How my Brother Leon Brought Home a Wife", which won first prize in the Commonwealth Literary Contest in 1921. Most of Arguilla's stories depict scenes in barrio Nagrebcan, Bauang, La Union where he was born. He became a creative writing teacher at the University of Manila and later worked at the Bureau of Public Welfare as Managing Editor of the Bureau's publication Welfare Advocate until 1943. He was later appointed to the Board of Censors. He secretly organized a guerilla intelligence unit against the Japanese. In October 1944, he was captured, tortured and executed by the Japanese army at Fort Santiago.

Kerima Polotan Tuvera (December 16, 1925 - August 19, 2011) was a Filipino author. She was a renowned and highly respected fictionist, essayist, and journalists, with her works having received among the highest literary distinctions of the Philippines. Some of her stories have been published under the pseudonym Patricia S. Torres. Born in Jolo, Sulu, she was christened Putli Kerima. Her father was an army colonel, and her mother taught home economics. Due to her father's frequent transfers in assignment, she lived in various places and studied in the public schools of Pangasinan, Tarlac, Laguna, Nueva Ecija and Rizal. She graduated from the Far Eastern University Girls' High School. In 1944, she enrolled in the University of the Philippines School of Nursing, but the Battle of Manila put a halt to her studies. In 1945, she transferred schools to Arellano University, where she attended the writing classes of Teodoro M. Locsin and edited the first issue of the Arellano Literary Review. She worked with Your Magazine, This Week and the Junior Red Cross Magazine. In 1949, she married newsman Juan Capiendo Tuvera, a childhood friend and fellow writer, with whom she had 10 children. Her short stories "The 
Trap" (1956), "The Giants" (1959), "The Tourists" (1960), "The Sounds of Sunday" (1961) and "A Various Season" (1966) all won the first prize of the Palanca Awards.

Ligaya Reyes (1910- ) Ligaya Victorio-Fruto finished elementary and high school at the Far Eastern University where her teachers encouraged her to write. She obtained her degree from the Philippine Normal School (now University), then taught in Baguio City. She has been married twice, first to Ramon Reyes, who died in 1944, and then to Larry Fruto, an engineer and who also died in 1979. She once worked for the Honolulu Star Bulletin, but quit in 1969 and writes occasionally for the newspapers. She also found work with the Manila Tribune, where her first husband also worked as illustrator. She also worked for the Manila Times and Graphic.

Victorio-Fruto started writing while still in high school. In Baguio her family stayed in the house of a woman with ten children and spent the evenings in storytelling. When her husband died, writing stories became means of extra income. While he pursued her journalistic career, She continued writing fiction for various publications. Seven of her stories were included in Jose Garcia Villa's honor roll of short stories, from 1926-1940. "Call of Gangsa,"1933; "The Singer Came Into the Garden" and "This is Christmas," 1936; "Boy Left Behind" and "On Record,"1937; and "Bus Ride" and "Maternity Leave," 1940.

Paz Marquez-Benitez (1894-) authored the first Filipino modern English Language short story, born into the prominent Marquez family of Quezon province, she was among the first generation of Filipinos trained in the American education system which used English as the medium of instruction. She graduated high school in Tayabas High School and college from the University of the Philippines with a Bachelor of Arts degree in 1912. She was a member of the first freshman class of the University of the Philippines, graduating with a Bachelor of Arts degree in 1912. Two years after graduation, she married UP College of Education Dean Francisco Benitez, with whom she had four children.

Though she only had one more published short story after "Dead Stars" entitled "A Night in the Hills", she made her mark in Philippine literature because her work is considered the first modern Philippine short story.

Aida Rivera-Ford (1929- ) was born in Sulu but crossed Negros Oriental in 1949 for an English degree at Siliman University. Records toast her as the first editor of Sands and Coral, the School's literary folio, In 1954, she flew the University of Michigan on a Fulbright grant to secure her master's degree in English.

Love in the Cornhusks is one of five well-crafted stories for which Rivera-Ford won the Jules and Avery Hopwood Prize in Michigan. In 1955, the story received uncommon praises, citing its masterful subtlety and also its earnest vision- a rare case of art prevailing upon all creeds and manners of persuasion. Two years later, Rivera-Ford released her five stories under the title Now and at the Hour and Other Short Stories.

Paz Latorena (1908-1953) was the youngest among the four children of Florencia Manguera and Valentin Latorena and was born in Boac, Marinduque. She finished basic schooling at St. Scholastica's College in Manila South High School. In 1926, she took up Education at the University of the Philippines in Manila where she also attended a short story writing class under a key figure in Filipino Literature in English, Paz Maquez Benitez.

In 1927, Latorena received an invitation from Benitez to write a column for the Philippine Herald Magazine, of which Benitez was the literary editor. That same year, Latorena, along with other campus writers, founded the UP Writers' Club.

Latorena also wrote poetry under the pseudonym, Mina Lys, which, according to Tanlayco, had a romantic significance for then the young writer. Before the year ended, the Marinduque native won the third prize in Jose Garcia Villa's Roll of Honor for the Best Stories of 1927 for her story, "The Small Key".

For her final year in college in 1927, Latorena transferred to UST to finish her Education degree. She became the literary editor of the Varsitarian and published her poems, "Insight" and "My Last Song" under her nom de plume Mina Lys. She shortly earned her master's and doctorate degree while teaching literature courses in UST. In 1934, her doctoral dissertation, "Philippine Literature in English: Old Voices and New," received the highest rating of Sobresaliente. In 1943, Latorena authored her last story, "Miguel Comes Home". She died a decade later, on October 19, 1953 of cerebral hemorrhage. 